\title{
A Bolyai-kutatás múltja és jelene \\ A Bolyaiak Erdély tudománytörténetének \\ meghatározó alakjai
}

\section{Kiss Elemér}

The Past and Present of the Bolyai Research - The activity and the results of the two Bolyais were unknown for their contemporaries.

How did the Mathematical society discovered them after their death?

Who had outstanding results in the research of their life and work in the last half century? What were the obstacles and difficulties of this research? How did the Bolyai cult accomplish at the beginning of the $20^{\text {th }}$ century? How did it develop in the following years? The present work wants to answer these questions and also wants to show some basic results obtained by the author.

Bolyai Farkas (1775-1856) és Bolyai János (1802-1860) neve az elmúlt 140-150 év során szorosan összefonódott. Ritkán történik meg, hogy egyazon tudományterületet bevilágító két lángelme oly egyszerre és egymáshoz oly közel fénylett volna, mint az apa Bolyaié és a fiú Bolyaié. A tudománytörténet nem hiába emelte őket a halhatatlan tudósok sorába, hiszen Bolyai Farkas és János életmüve a korszak erdélyi magyar művelődésének, tudományának csúcsteljesítménye.

Kettejük közül Farkas volt a hatalmasabb s színesebb. Alighanem a legsokoldalúbb ember volt, aki magyar földön élt - írja Németh László. A matematikai kutatómunkát a maradandó felfedezések színvonalán mủvelte. Eredeti ötletei voltak az algebra, geometria, analízis terén, de izgatták a számelmélet vonzó feladatai is. Önálló gondolatai ma már a matematika szerves részei.

Bolyai János a magyar tudomány legnagyobb büszkesége, aki az 1831ben megjelent munkájában korszakalkotó eredményt ért el. Megtörte az euklideszi geometria egyeduralmát, felszabadította az utat az emberi gondolkodás előtt a tér másként való felfogása számára. Nagy mủvének megalkotása után sem pihent. Napestig ült íróasztala mellett, hogy fóliáns 
nagyságú papírjait vagy sokszor apró papírszeletkéit teleírja, rögzítse gondolatait. Figyelmét föképpen a matematika különböző fejezetei kötötték le, ám ugyanakkor egy pillanatra sem tévesztette szem elől, hogy „semmiféle egyéni üdv nem állhat fenn a közüdv nélkül."

Sokszor emlegetjük, hogy a két Bolyai matematikai tevékenysége észrevétlen maradt a kortársak előtt. Valóban, mindketten elismerés és siker nélkül, a meg nem értettség fájó érzésével hunyták le szemüket. Gauss Bolyai Jánost csak magánlevélben nevezte elsőrangú lángésznek, nyilvánosság előtt sohasem nyilatkozott róla. Az Appendixet többen is olvasták (W. von Eckwehr, G. A. Greisinger, a „derék” A. Ettingshausen, C. L. Gerling, J. J. Littrow), s bár közöttük egyetemi tanárok is voltak, nem tudták befogadni az új eszméket.

A következökben tekintsük át, hogy az elmúlt másfél évszázad folyamán kik is alkottak maradandót a két Bolyai életművének feltárása során. Irásunk első részében többször támaszkodunk a nemrég elhunyt neves debreceni matematikatörténész, Szénássy Barna rendkívül alapos tanulmányára, amelyet Fejér Lipót hagyatékának rendezése és feldolgozása táplált.

Elöljáróban mindjárt el kell mondanunk, hogy a Bolyaiak „felfedezésének" úttöröi nem magyarok voltak. A történet külföldön kezdődött. Ebben nagy szerepet játszott Gauss 1855-ben bekövetkezett halála után hagyatékának feldolgozása. A hagyatékot Sartorius von Waltershausen göttingai professzor rendezte, akinek Bolyai Farkas is megküldte Gaussnak hozzá intézett leveleit és a tỏle kapott emléktárgyakat. Ezt az anyagot is figyelembe véve írta meg 1856-ban Waltershausen Gauss zum Gedächtnis (Gauss emlékezete) címü könyvét. Ebben a munkában olvashattak külföldön elöször Bolyai Farkasról és Bolyai Jánosról. Waltershausen könyve alkalmas volt arra, hogy fölhívja a matematikusok figyelmét a Bolyai névre, bár egyik Bolyai matematikai tevékenységét sem ismertette. A könyvet a marosvásárhelyi születésű, a kollégium diákja és későbbi német szakos tanára, Göldner Nándor fordította magyarra és az - csak a fordító halála után - 1903-ban (és 1911-ben is) jelent meg Breznóbányán.

Az első, nyomtatásban olvasható elismerő szavak a két Bolyai néhány matematikai eredményéről Richard Baltzer drezdai matematikaprofesszortól származtak, amelyeket az 1860-62-ben megjelent Die Elemente der Mathematik címü, jól ismert és nagy hatású könyvében írt le.

A Bolyai-geometria történetének legjelentősebb dátuma 1867, amikor az Appendix francia nyelven is megjelent Guillaume-Jules Hoüel bordeaux- 
i matematikaprofesszor forditásában, aki Baltzer révén szerzett tudomást Bolyai János tevékenységéről. Mintegy másfél évtizeden át Hoüel volt a Bolyai-ügy legfáradhatatlanabb harcosa. İgy jellemezte János müvét: „Ez az Appendix egy hatalmas értékü munka." Említsük meg Szabó Sámuel marosvásárhelyi, majd kolozsvári tanárhoz írt érdekes levelét, amelyben Gaussnak Bolyai Jánosról való hallgatásán csodálkozik. Hoüel 1867 novemberében ezt írja: „Schumacherrel folytatott levelezésében Gauss több ízben tárgyalja a paralelák elméletét. [...] Gauss ezek egyikében sem idézi Bolyai Jánost, holott munkáját még a Lobacsevszkijé elött kellett ismernie. [...] Ezek után nem értem, miért nem idézte Gauss Bolyai Jánost Lobacsevszkijnél preferáltabban, annál is inkább, mivel az Appendix messze felülmúlja az orosz matematikus munkáját."

Hoüel érdeklődő kérdéseire Schmidt Ferenc épitészmérnökben talált rendkívül lelkes segítötársra. Schmidt éppen Hoüel kérésére írta meg a két Bolyai életrajzát és közölte a Grunert-féle Archivban. Ez az értekezés ismertette elöször világnyelven a két Bolyai életrajzi adatait. Az Appendix francia fordítása is a Schmidt Ferenc által írott életrajzzal egybefüzve jelent meg. Hoüel a Schmidt-értekezést igen jónak találta, és megérkezése után azonnal bemutatta a bordeaux-i akadémia egyik ülésén. Bizonyos, hogy ez volt a két Bolyairól szóló első előadás mind Magyarországon, mind külföldön.

A tér abszolút igaz tudományának francia kiadásával szinte egyidőben, 1868-ban, megjelent az olasz nyelvủ változat is Baldassare Boncompagni herceg, neves matematika- és fizikatörténész szorgalmazására és támogatásával. A forditás Giuseppe Baltaglini, a nápolyi, később a római egyetem geometriaprofesszorának müve.

A bordeaux-i kiadvány hatására itthon is felismerték a Bolyai-ügy jelentőségét. Hunyady Jenő az Akadémia egyik ülésén tájékoztatta a tagokat arról, hogy megjelent francia nyelven az Appendix. Azt indítványozta, hogy az Akadémia kérje kölcsön Marosvásárhelyről feldolgozás céljából a Bolyaihagyatékot. Az Akadémia akkori főtitkára, Arany János 1868. június 15-én írt levelében kéri a Kollégium igazgatóságától az iratokat átvizsgálásra.

A hagyaték végül 1869 decemberében gróf Teleki Domokos személyes közvetítése útján megérkezett Pestre, és felbontatlanul „letétetett” az Akadémia Levéltárába.

Hoüelnek a Bolyaiak iránti érdeklődése ez idő tájt sem lankadt. Figyelmének középpontjában ettől kezdve a hagyaték, különösen annak matematikai része feldolgozásának és közzétételének ügye állott. Egészséges 
türelmetlenségét mutatják a Schmidt Ferenchez írott levelei. Az egyikböl idézünk: „Határozottan kezdem elhinni, hogy a geográfusok tévedtek, amikor Erdélyt Európába rajzolták ... Bizonyos, hogy ha a Bolyai-iratok Japánban vagy Ausztráliában lettek volna, akkor Ön már régen megkapta volna azokat." Hoüel mellett az olasz B. Boncompagni is sürgette a kéziratok átvizsgálását. Levelet írt Eötvös József kultuszminiszternek, aki ekkor a Magyar Tudományos Akadémia elnöki tisztét is betöltötte. Ezzel a levéllel kapcsolatban így ír Eötvös fiához, Eötvös Lorándhoz 1869. július 9-én: „... A napokban levelet kaptam a római akadémia matematikus osztálya elnökétől, melynek örültem és elszomorodtam egyszerre, s melynek tartalmáról most sem tudom, büszkék legyünk-e reá, vagy piruljunk." Eötvöst azért kereste meg Boncompagni, "mert a külföldi tudósok meg lévén győződve, hogy ilyen lángész irományai között sok becses jegyzet lesz, azokra kezemet tegyem, sérdemes részét vagy az akadémiánál adjam ki, vagy nekik engedjem át kiadás végett."

Végül az MTA III. osztályának 1871. október 16-i határozata értelmében megalakult a Bolyai-hagyaték átvizsgálására hivatott négytagú bizottság, melynek elnöke Vész János, s tagjai Hunyady Jenö, König Gyula és Schmidt Ferenc építész voltak. Sajnos a kéziratos hagyaték feldolgozása vontatottan haladt. Az Akadémia 1874. március 16-i ülésének jegyzőkönyve szerint „Bolyai munkájának elkészülte bizonytalan, miután ez oly természetủ, hogy rögtönözni nem lehet, és sokszor tetemes anyag feldolgozása után sincs közölhetö eredmény".

A Bolyai-iratok 1894-ig maradtak Pesten. Ekkor az MTA III. osztálya az alábbi határozatot hozta: „A szintén már hosszabb idő előtt beadott jelentések (König Gyula és Schmidt Ferenc részéről) értelmében ezen iratokban kiadásra alkalmas anyag nem találtatván, az osztály részéröl nem forog fenn nehézség aziránt, hogy ezen iratok jogos birtokosuknak visszaadassanak."

Huszonöt év alatt tehát nem sikerült új tudományos eredményeket felfedezni a hagyatékban. Mégis van két feljegyezni való esemény. Az egyik 1884-ben történt, amikor Schmidt Ferenc Márton nevü fia a kéziratokat nézegetve rábukkant a nevezetes temesvári levélre. Ugyancsak Budapesten találtak rá Bolyai ifjúkori jegyzeteire, közöttük a Parallelarum Theoriara címü négy ábrára, melyekből kiolvashatók az új geometria gondolatai.

A Kolozsvári Tudományegyetem 1872 öszén nyitotta meg kapuit. Létesítése az erdélyi tudományos élet kimagasló eseménye volt. A századforduló idején már az ismert és elismert intézmények közé tartozott. Azok 


\section{EME}

között, akik a kolozsvári egyetemet európai szintre emelték, bátran mondhatjuk, hogy a matematikaprofesszorok az élen jártak. Tevékenységükkel az új egyetem azonnal a Bolyai-tradíció hủ ápolójává vált. A múlt század utolsó évtizedeiben így alakult ki nálunk a két Bolyai eredményeire támaszkodó, azok irásaiból táplálkozó tudományos irodalom.

Réthy Mór a kolozsvári egyetemen már 1874-ben - alig két évre J. Frischauf grazi tanár után - clöadást tartott az abszolút geometriáról. Réthy az új geometria ismertetése és népszerűsítése terén jelentős munkát végzett.

Tanítványának, a marosvásárhelyi születésủ Vályi Gyula buzgó munkásságának köszönhető, hogy Kolozsvár a Bolyai-kultusz fellegvára lett. Vályi Gyula az 1881-82-es tanév második félévétől kezdve kurzusszerủ elöadásokat tartott, amelyek keretében rendszeresen ismertette az Appendix anyagát.

Réthy Mór Bolyai Farkas eredményeinek továbbfejlesztésében is jelentős szerepet vállalt. Különösen a Bolyai Farkas által vizsgált „végszerü területegyenlöség" kérdését kutatta. Vizsgálataihoz többen is csatlakoztak, máig pedig ezt a problémát az értekezések hosszú sora tárgyalja. Kétségtelen, hogy ez Bolyai Farkas egyik legfontosabb és a világirodalomban legtöbbet idézett eredménye. Elég ha Gerwien, Max Dehn, Kagan, Killing, Schur, Szász Pál idevágó dolgozatait említjük.

Farkas Gyula foglalkozott az ún. trinomegyenletekre vonatkozó - a Tentamenben röviden tárgyalt - gyökközelítő eljárással. Ennek révén a Bolyai algoritmus igen ismertté vált, alkalmazásaival, általánosításaival több magyar és külföldi matematikus is szép eredményeket ért el. A témában már a XIX. század végén több dolgozat jelent meg külföldi (Astrand, Dickson, Netto és mások) szerzöktöl. A magyarok közül Rényi Alfréd és Veress Pál munkáit említjük.

A XIX. század utolsó évtizedeiben a Bolyaiak szülőföldjén sem lelkesedett mindenki egyformán nagyszerủ felfedezéseikért. A kortársak és a következő nemzedék által is tisztelt tudós, Brassai Sámuel volt az, aki sajnos nem értette meg a két Bolyai munkáit és ezt hangoztatta is. Kijentette: „Az Appendix hatalmas ostobaságot szült, mely abszolút geometriának nevezi magát, de ez sem nem abszolút, sem nem geometria, hanem csak árnyjáték”, és „Bolyai Farkas nekem, legmélyebb tisztelőjének, semmi olyant nem alkotott, amit én a nagy közönségnek felmutatni bírnék". 
Brassai vélekedése nem volt elszigetelt jelenség. Angliában Cayley volt a nem euklideszi geometria legcsökönyösebb ellenfele, Oroszországban Osztrogradszkij, Bunyakovszkij támadta Lobacsevszkijt („Lobacsevszkij úrnak a Geometriája nem egyéb közönséges bohózatnál" - írta Osztrogradszkij), Franciaországban J. Bertrand, Németországban pedig Dühring ellenállása volt a legerősebb. Ez a szenvedélyes ellenkezés még akkor sem szünt meg teljesen, amikor Beltrami, Cayley, Klein, Poincaré s a magyar König Gyula modellt konstruáltak, amellyel bebizonyították, hogy a Bolyaigeometria nem ellentmondásos.

A magyar tudomány 1897-ben törlesztette Bolyai Jánossal szemben régi adósságát. Ismét a lelkes Schmidt Ferenc volt az, aki a nyomdai munka anyagi terhét is vállalva megjelenteti az Appendixet magyarul (amikor már van francia, olasz, angol, sőt japán kiadása is). Ugyancsak ő szorgalmazta a Bolyai Farkas és Gauss közötti levelezés kiadását. Fáradozását 1891-ben koronázta siker. A kiadást egy fiatal matematikussal, Paul Stäckellel készítették elö.

Stäckel komoly érdemeket szerzett a Bolyai-kutatásban. Az ő áldozatos munkájának köszönhető, hogy Bolyai János kéziratban maradt matematikai munkáinak egy része a századforduló idején napvilágra került. Kutatásainak eredményeit az értekezések egész sorában tette közzé. Kétkötetes könyve ma is az az alapmü, amely a két Bolyai életének és tevékenységének legteljesebb képét adja.

Stäckel Marosvásárhelyre is ellátogatott, hogy minél alaposabban tanulmányozhassa a Bolyaiak munkáját. A másik külföldi matematikus, aki a Bolyaiak kedvéért 1896-ban Marosvásárhelyre utazott, Halsted amerikai egyetemi tanár. Ö fordította 1891-ben angolra az Appendixet és neki köszönhetően találkozott először Bolyai nevével az angolszász világ. Az Appendixet több helyen az emberi gondolkodás története legkiemelkedőbb huszonhat oldalának nevezi. Halsted biztatására írta meg Bedőházi János kollégiumi tanár a Bolyaiak első monográfiáját 1897-ben. Az 1897. év harmadik nagy eseménye: ekkor mutatta be König Gyula az Akadémia egyik ülésén a Tentamen második kiadásának első kötetét (a második kötet 1904ben jelent meg).

Elérkezett 1902, Bolyai János születésének 100. évfordulója. A centenáriumi ünnepségeket Bolyai szülővárosában, Kolozsvárott tartották 1903. január 15-én. Az előkészítési munkában oroszlánrészt vállalt két kiváló tudós: Farkas Gyula és Schlesinger Lajos. A kolozsvári egyetem meghívta az 
Akadémiát is az ünnepi ülésre. Az MTA küldöttségét báró Eötvös Loránd elnök vezette, tagjai: Szily Kálmán fơtitkár, a III. osztály titkára, Réthy Mór rendes, Kürschák József és Tötösy Béla levelezö tagok voltak.

Az emlékbeszédet - amely a Bolyai-irodalom egyik fontos alapmunkája - Schlesinger Lajos tartotta. Ó kutatta fel Bolyai János szülőházát, amelyet ekkor emléktáblával jelöltek meg. Az alkalomra az egyetem egy szép latin nyelvủ tanulmánykötetet adott ki, ez nemsokára magyarul is megjelent. Az ünnepségen részt vett Bolyai János fia, Bolyai Dénes, továbbá a marosvásárhelyi református kollégium küldöttsége és számos intézmény képviselője.

Tíz nappal később, 1903. január 25-én Marosvásárhelyen ünnepelték Bolyai János születésének századik évfordulóját.

A szép megemlékezések utáni évtizedek során is mindig akadtak akik ápolták a két matematikus emlékét. Számos tudományos dolgozat, népszerü írás jelenik meg a különböző folyóiratokban, lapokban. Ekkor készül el az első olyan, magyar tudós által írt disszertáció, amelyik témáját a Bolyaigeometriából merítette (Király Henrik: Az állandó görbületü felületeken érvényes geometriáról, 1901).

Vezetője Schlesinger Lajos volt. Igen értékesek Szabó Péter munkái. Amint közismert, az MTA Könyvtára Bolyai-gyüjteményének jelentös része az ő adománya révén keletkezett. A Bolyai-geometriával foglalkozik Vörös Cirill több dolgozatban. Ezekben az években (1913-ban) közli Gulyás Károly marosvásárhelyi rajztanár, a Teleki Téka öre, Bolyai Farkas zenészeti dolgozatát és ír Farkas festményeiröl (1913). A Bolyai-kutatásban új adatokkal szolgált Kintses József, amidőn 1911-ben közreadta Bolyai Farkas erdészeti csonka munkáját.

1911. június 7-én exhumálták a két Bolyait, Farkast és Jánost és helyezték közös sírba, oda, ahol ma is nyugodnak a marosvásárhelyi református temetőben. Valószínúleg az esemény hatására írta meg ekkor Babits Mihály Bolyai-szonettjét, a legszebb, legtömörebb költői mondanivalót Bolyai új, más világával kapcsolatban (a vers 1911 szeptemberében jelent meg a Nyugatban). Babits verse és Ady Endre költői látomása után („Megnyíltak lángolván elöttünk / a Bolyai-s Csere sírok") a Bolyaiak irodalmi hősökként is bevonultak a köztudatba.

Fontos dátuma a Bolyai-kutatásnak az 1923-as év. Bedőházi és Stäckel müvei után ekkor jelent meg Dávid Lajos $A$ két Bolyai élete és munkássága címủ monográfiája, amely majdnem három évtizeden át a Bolyai-kutatások egyik legfontosabb kézikönyve volt. Dávidnak nem volt lehetősége (ekkor) 
hozzáférkőzni a marosvásárhelyi kéziratokhoz, ezért megkérte magántanárát, Jelitai Józsefet, hogy utazzon Marosvásárhelyre és tanulmányozza a kéziratos hagyatékot. Jelitai vizsgálata eredményéröl több közleményben számolt be később.

Az 1930-as évek közepén találkozunk elöször Szénássy Barna nevével, aki Bolyai Farkas infinitézimális gondolatai címủ disszertációját publikálja 1937-ben. Dolgozatában rámutat többek között Bolyai Farkasnak a végtelen sorok konvergenciájával kapcsolatos eredeti felfedezéseire. A későbbi évtizedekben Szénássy az igen alapos, pontos könyveivel, tanulmányaival a Bolyai-kérdés egyik legavatottabb, sokat idézett kutatójává vált.

Az ötvenenes években nagyot lendült előre a Bolyai-kutatás. 1952-ben a kolozsvári Bolyai Tudományegyetem vezetösége elhatározta, hogy névadója születése 150. évfordulóját nagyszabású kiállítással és emlékkönyv kiadásával ünnepli meg. Budapesten az MTA rendezett ünnepi ülést. Az évfordulóról a Román Akadémia sem feledkezett meg. Az ünnepségek számos matematikust, tudománytörténészt, közírót serkentettek munkára. Magyarországon 1952-ben két Bolyai-könyv jelenik meg Alexits György és Kárteszi Ferenc tollából. Előzőleg Dávid Lajos a külföld számára, Svájcban jelenteti meg Die beiden Bolyai címü munkáját. Ne felejtsük el Dávid $A$ Bolyai-geometria az Appendix alapján címü könyvét se, amely Kolozsvárt született az 1944. év baljós augusztusában, és alighogy a városon átviharzott a háború, a nyomda raktárából egyenesen a zúzdába vitték a köteteket.

1953-ban jelent meg a kolozsvári Bolyai Tudományegyetem gondozásában a Bolyai János élete és müve címü tanulmánykötet. Ebben a kötetben olvashattunk végre több „szemelvényt” Bolyai János kézirataiból Benkő Samu, Szarvadi Tibor és Tordai Zádor összeállításában, valamint a két Bolyai leveleiből és levéltöredékeiből Jakó Zsigmond gyüjtése nyomán.

Bukarestben Tóth Imrének jelenik meg Bolyai Jánosról írt életrajza magyar, román és német nyelven. 1954-ben ö fordítja le románra az Appendixet.

A budapesti és kolozsvári kiadványok alkalmasak voltak arra, hogy felhívják a figyelmet a további feladatokra. Bizonyossá vált, hogy mind Marosvásárhelyen, mind Budapesten még bőven vannak kutatásra váró, korábban figyelembe nem vett kéziratok.

Bolyai Farkas és János kéziratos hagyatékát (mintegy 20000 oldal) a Budapestről 1894-ben történt visszaszállítás óta a kollégium könyvtárában őrizték, majd átkerült a Teleki Tékába, de mondhatjuk, hogy nagyon 
kevesen háborgatták. János kéziratairól már a kortársak is tudtak és azt is megsejtették, hogy azok valamilyen titkokat rejtenek. A marosvásárhelyi várparancsnok a katonai titkoktól félt, $s$ azért foglaltatta le az iratokat, Dósa Dániel azonban így ír a Kolozsvári Közlönyben megjelent nekrológjában: „... mert nagybecsü kéziratait nem adhatá, elhatározott célja szerint sajtó alá, $s$ kérdés vajon sikerülend-e avatott kezeknek úgy rendbeszedni és világ elébe bocsátani, hogy magas értékök szerint méltó elismerést vívjanak ki." Alig hét évvel később a marosvásárhelyi kollégiumban tanító Szabó Sámuel (Péter apja) Schmidt Ferenchez intézett két levelében olvashatunk a kéziratokról. Az egyikben jelzi, hogy átlapozta a Bolyai-hagyatékot, ez rendkívül szennyezett és rendezetlen, hosszú időt fog még igénybe venni feldolgozásuk. A másik levélböl megtudjuk, hogy 1867. május 29-én a Református Egyház Főkonzisztóriuma Kolozsvárott elrendelte a kézírásos hagyaték feldolgozását. Sajnos a határozat végrehajtásának akkor hiányoztak az itthoni feltételei. De Bedőházi János is panaszkodott az iratokra: „Annyit mondhatok, hogy egyiptomi hyeroglyphákat megfejteni könnyebb dolog, mint az ő írásaiból valamit kitudni" - írja 1897-ben Schmidt Ferencnek.

Valóban nem könnyü olvasni és megérteni Bolyai írását. Másrészt, ha a Bolyai-irodalmat olvassuk, gyakran tapasztaljuk, hogy tekintélyes szerzők (így maga Stäckel, de Kárteszi Ferenc, Alexits György és mások is) szinte lebeszélnek a kutatásról, kilátástalannak, reménytelennek tartják a búvárkodást.

Szerencsére, ennek ellenére az 50-es évek elején Benkő Samu személyében akadt egy kitartó, szivós kutató, aki vállalkozott a kéziratos hagyaték rendezésére (ebben segítséget talált Abafáy Gusztávban), feldolgozására. A kéziratlapokat palliumokba helyezték és megszámozták. Ezáltal könnyen kezelhetökké váltak, hivatkozni lehet az egyes oldalakra, ellenőrizni a hivatkozást. Nagy segítség ez azoknak, akik a kéziratokat tanulmányozzák. Benkő Samu, akinek neve a következő ötven év során összeforrott a Bolyai-kutatással, feladatának mindenben eleget tett, s amikor lehetőség kínálkozott rá, munkájának eredményét számos könyvben, tanulmányban ismertette.

Benkő Samu munkáit Magyarországon először Vekerdi László köszöntötte. „Benkő Samu Bolyai János vallomásai címü, alapvető s forrásértékü monográfiájában - írja Vekerdi László - föltárta azokat a kulturális, gazdasági és társadalmi körülményeket, melyek elengedhetetlen minimális feltételként szolgáltak, hogy egy ekkora változást megvalósító alkotás, mint 
Bolyai remeke, létrejöhessen.” „Egyszerủ és új szempontból vizsgálja Benkő Samu Bolyai János egész kéziratos hagyatékát, először a Bolyai-kutatás évszázados történetében ... Bolyai Jánosról sokféle képet rajzoltak, de Benkő Samu most megjelent monográfiája az első írás, mely a képek mögött az emberig férkőzött."

Az elkövetkező öt évtizeden át Benkő Samu kisebb-nagyobb megszakításokkal szorgalmasan publikál, ám a XX. század második felében számos új névvel találkozunk, akik a két Bolyai életmúvét kutatják, tanulmányozzák, cikkeket, könyveket írnak. Egyre jobban gazdagszik, terebélyesedik a Bolyai-irodalom. A kutatók az életművek különböző oldalainak feltárásán fáradoztak. Megjelennek Tóth Imre könyvei, cikkei a nem euklideszi geometria filozófiai jelentőségéröl. „Senki Tóth Imréhez foghatóan nem ismeri a nem euklideszi geometriák matematikai, történeti, filológiai és filozófiai rejtélyeit" - írja ismét Vekerdi László. A dokumentumok közvetlenségéből, áradó bőségéből közelít Bolyai János alakjához és sorsához Sarlóska Ernő. Az Akadémiai Könyvtár kézirattárában őrzött gazdag kéziratos anyag tanulmányozása során jutott arra a meggyőződésre, hogy Bolyai János szokásos megítélése téves, kivált ami az oly fontos ifjúi éveit és katonai szolgálatát illeti. A fizika és Bolyai János munkássága kapcsolatával Toró Tibor és Gábos Zoltán foglalkozott és foglalkozik ma is. Toró Tibor számos könyv és tanulmány szerzője, az általános relativitás-elmélet alapjainak vizsgálata során Bolyai és Einstein között fedezett fel szellemi kapcsolatot, ám érdekli a nevezetes temesvári levél sorstörténete és Babits Mihály Bolyaiszonettjének különböző nyelvekre való fordítása is. Gábos Zoltán Bolyai egyik feljegyzését vizsgálva megállapítja, hogy „Bolyai Jánost az abszolút tér első bírálói közé kell sorolnunk". A Bolyaiak zeneelméletével Benkő András, Farkas aforizmáiról Kozma Béla, „szemészetéröl” Fodor Ferenc és Tófalvi Zoltán írt könyvet, Ács Tibor pedig Bolyai János bécsi éveiről, katonai és hadmérnöki pályafutásáról értekezett. Nem szabad megfeledkeznünk Fráter Jánosnénak a Bolyai-gyüjteményről összeállított ismertetőjéről, amely minden kutatás értékes munkaeszköze, és a két Bolyai könyvtáráról Deé Nagy Anikó által készített kitűnö, részletes tanulmányról.

Bolyai Farkasról és Jánosról a múlt század utolsó negyedében értékes összefoglaló munkák jelentek meg Magyarországon Szénássy Barna, Kálmán Attila, Erdélyben Benkö Samu, Neumann Mária - Salló Ervin - Toró Tibor, Mandics György - M. Veress Zsuzsánna, Weszely Tibor tollából. Magyarországon újra kiadják bővitett formában Alexits György, Kárteszi 
Ferenc és Dávid Lajos munkáit. Értékes tanulmányok láttak napvilágot a Tiszatáj 1975-ös Bolyai Farkas-emlékszámában és az Igaz Szó szépirodalmi ihletésủ Bolyai-emlékszámában, valamint korábban a marosvásárhelyi Bolyai-emlékkönyvben. Budapesten a Magyar Tudományos Akadémián emlékeztek meg Bolyai János születésének 175. évfordulóján, halálának 125. évfordulóján pedig a Tudományos Ismeretterjesztő Társulat rendezett emlékülést. Az elöadások Staar Gyula szerkesztésében jelentek meg. Kolozsváron a Babeș-Bolyai Egyetemen tartottak megemlékezö ülést Bolyai János születésének 175. évfordulóján.

Megemlítjük, hogy 1979-ben (majd 1989-ben is) jelent meg Jeremy Gray neves angol matematikatörténész Gondolatok a térröl címü könyve, amelyben tág teret szentel a két Bolyainak is. Ezzel összefüggésben kell megjegyeznünk, hogy sajnos a mai napig sincs angol nyelven elegendő irodalom a Bolyaiakról. Enélkül pedig Bolyai Farkas és János munkásságának értékelése nem fog a helyére kerülni a nemzetközi irodalomban.

Bár Bolyai János kézírásos matematikai hagyatékát Hoüel már 1869ben szerette volna közzétenni, ez a munka 120 évvel később is váratott magára. Az irományok matematikai természetủ részét Benkő Samuék sem tanulmányozhatták, nem lévérı szakemberek. Benkő Samu így panaszkodott egyik írásában: „... matematikatörténeti iskolázottság híján szüntelenül elégedetlenkedtünk magunkkal, hogy alig hasznosíthattunk valamit a szövegek kínálta belső összefüggésekböl."

Végül az 1990-es évtized folyamán sikerült a kéziratokban rejlő matematikai „kincseket” is megérteni és feltárni. Bizony jól sejtette már Dósa Dániel, Hoüel és Eötvös József is, hogy a kéziratokban sok érték van. A kézirathagyaték lapjai, az újabban megismert több Bolyai-levél arról győznek meg, hogy a geométerként ismert Bolyai János egyetemes matematikai zseni volt, akit a matematika minden ága érdekelt, és aki korának számos alapvető problémájával foglalkozott, olykor évtizedekkel megelőzve más nagy nevekhez füződő felfedezéseket.

A kéziratok olyan matematikai igazságokat, tételeket rejtegettek, amelyek Bolyai halála után 40-50 évvel jelentek meg különböző publikációkban. Ezek a tételek ma nem Bolyai Jánosnak, hanem újrafelfedezőjüknek nevét viselik. Ha a Bolyai-iratok átvizsgálásával megbízott testület tagjai abban az időben, amikor a hagyaték 1869 és 1894 között az Akadémia levéltárában porosodott, alaposan átvizsgálják a kéziratokat, bizonyára rábukannak a 
Bolyai-tételekre, s akkor azokat ma valódi felfedezőjük, Bolyai János nevével tartaná számon a matematika története.

Ha megkésve is, de Bolyai nem geometriai felfedezéseit sikerült angolul is közzétenni. Ennek köszönhető, hogy már a nemzetközi matematika is felfigyelt rájuk. A közelmúltban, 2004-ben megjelent a Fermat-féle számokról írt egyik rangos monográfiában Bolyai két számelméleti tételét is idézik. Ezek egyikét - mivel sem Bolyai előtt, sem utána senki más sem fedezte fel - a szerzők teljes joggal Bolyai tételének nevezték el. A magyar szakkönyvek közül eddig egyedül Bege Antal kolozsvári kollégánk idézi Bolyai János egyik tételét. Reméljük, hogy az elkövetkező években az angol nyelvű könyv nyomán magyar munkákban is megjelennek Bolyai számelméleti, algebrai és az analízishez tartozó felismerései.

Mindezek a kutatások már a jelenhez tartoznak. Talán fölösleges hangsúlyoznunk, de ma már csak az eredeti források tanulmányozásával mondhatunk újat. Az utóbbi években ezt a nem könnyű munkát vállalta Oláh Gál Róbert, aki nagy szorgalommal és kitartással búvárkodik a levéltárakban és talál felderíteni valót. Különösen értékesek a Bolyai család történetére vonatkozó munkái. Olyan forrásokat kutatott fel Bécsben, Budapesten és Marosvásárhelyen Ảcs Tỉbor, melyek korábban a tudományos világ számára ismeretlenek voltak, és ezek tömege által segitve nem elbeszéli, hanem a szó eredeti értelmében demonstrálja, miként élt és tanult, hogyan haladt a katonai ranglétrán Bolyai János. Vaskos könyvében elsődleges forrásokat használva felvázolja Bolyai hadi mérnöki pályafutását, szolgálatának temesvári, aradi, lembergi, olmützi eseményeit, végül nyugdíjas életének hétköznapjait.

Bolyai János betegségeiről az elmúlt évtizedekben az orvosi szakirodalomban több írás látott napvilágot. Ezekben olyan tüneteket tulajdonítottak neki, amelyekre alapozva elmebajjal is megvádolták. Sokáig kellett várni arra, hogy Bolyai János orvosi receptjeit, betegsége leírt tüneteit megvizsgálva, hozzáértő szakember felelősen nyilatkozzék a kérdésről. Erre csak napjainkban került sor, amikor Jung János orvosprofesszor szakszerủen elemezte a korabeli orvosi dokumentumokat, megcáfolva a gyengén alátámasztott, szubjektív és rosszhiszemủ adatokra hivatkozó véleményeket.

Gyakran panaszkodunk amiatt, hogy a Bolyai-kutatásban nem találkozunk fiatalokkal. Sajnos a bánatunk valós. Talán ezért örültünk olyan nagyon, amikor két-három éve egy fiatal szegedi matematikus jelentkezett Bolyai Farkas kéziratainak tanulmányozásával. Szabó Péter Gábor, mert 
róla van szó, Bolyai Farkas számelméleti vonatkozású jegyzeteit nézte át, bebizonyítva ezáltal, hogy ő is eredményesen foglalkozott a matematikának ezzel a szép ágával. Ugyanakkor sikerült megtalálnia néhány olyan matematikai csomópontot, ahol a két Bolyai vizsgálatai találkoztak. Azt már tudtuk, hogy több számelméleti probléma megválaszolására éppen Bolyai Farkas kérte meg fiát, ám jóleső érzés tölt el, amikor kéziratai között egy olyanra találunk, amelyre fia szép bizonyítását másolta le ezzel a megjegyzéssel: „Ezt János találta az enyim után”.

2002-ben ünnepeltük Bolyai János születésének bicentenáriumát. Ez az év egészében a Bolyai Jánosra való emlékezés jegyében telt el. Magyarországon és Erdélyben számos rendezvényen, közöttük több nemzetközi konferencián elevenítettük fel a legnagyobb magyar tudós munkásságát. Ausztriában, Szerbia-Montenegróban, Németországban, Franciaországban is voltak Bolyai-megemlékezések, ám tudunk arról is, hogy a tengeren túl, Chilében háromnapos, az USA-ban két helyen, New Yorkban egynapos, New Brunswickban (New Jersey állam) kétnapos Bolyai-konferenciát szerveztek. A Román Akadémia Bukarestben 2002. december 13-án emlékezett meg Bolyai születésének 200. évfordulójáról. Budapesten Prékopa András akadémikus szervezésében, számos külföldi résztvevő jelenlétében rendeztek egyhetes, nagyszabású konferenciát, Kolozsvárt 2002 októberében és decemberében, Marosvásárhelyen pedig 2002 júliusában és decemberében voltak méltó ünnepségek. Az erdélyi rendezvényekről Kása Zoltán, a Marosvásárhelyen meghirdetett Bolyai-évről pedig Csegzi Magdolna számolt be a Természet Világa hasábjain.

Az évforduló ugyanakkor serkentően hatott a könyvkiadásra is. Budapesten a Természet Világa folyóirat Bolyai-különszáma, a Gazda István által szerkesztett Egy halhatatlan erdélyi tudós, Bolyai Farkas címü tanulmánykötet, Ács Tibor vaskos munkája, Bolyai János új arca - a hadi mérnök, a Vince Kiadó tanulmánykötete, a Bolyai-emlékkönyv, a Kluwer Kiadó angol nyelvü tanulmánykötete jelent meg. Tóth Imrének rövid idő alatt három könyvét jelentetik meg különböző budapesti kiadók. Marosvásárhelyen a Mentor adta ki $A$ tér úttöröje, Kolozsváron pedig a Kása Zoltán által szerkesztett Bolyai János 1802-2002 három nyelvủ (magyar, román, angol) tanulmánykötet és az EMT által kiadott Bolyai-emlékkönyv látott napvilágot. Dávid Gyula szerkesztésében a Polis Könyvkiadó Bolyai címü díszes albummal a „versekben tündöklö” matematikust idézte meg. Benkő Samu Bolyai János vallomásainak negyedik, a Bolyai-levelek második kiadását és Bolyai 
János Marosvásárhelyen örzött kéziratai első kötetét vehette kézbe az olvasó. Ugyancsak Kolozsvárt adta ki Bitay László Mi a Bolyai-geometria? címü munkáját, a Korunk egy újabb Bolyai-különszámmal ünnepelte nagy matematikusunk születésének évfordulóját. Szegeden a Polygon Kiadó jóvoltából díszes formában jelent meg az Appendix három nyelvű (latin, magyar, angol) szövege. Csíkszeredában Oláh Gál Róbert Gondolatok Bolyai Jánostól és Bolyai Jánosról címen írt könyvet.

Külföldön két Bolyai-könyv jelent meg az utóbbi években. 1999-ben Annemarie Maeger magánkiadásában látott napvilágot a szép címü Bolyai János a matematika Mozartja munka német nyelven, 2004 nyarán pedig a már említett Jeremy Gray tette közzé Bolyai János, nem euklideszi geometria és a tér természete címủ angol nyelvü könyvét.

A Bolyai-kérdésben különlegesen jártas Vekerdi László évtizedek óta figyelemmel kíséri a Bolyai-kutatás minden rezdülését. Tudománytörténeti dolgozatai mellett számos tanulmányt szentelt a Bolyaiak tevékenységének is. Az ő 2003-ban leírt szavaival zárjuk írásunkat. „A Bolyai-kutatás beérkezett. Külön és értelmes diszciplinává nemesedett, ahonnét - remélhetőleg végleg - kiszorultak a jó (és a rossz) szándékú dilettánsok. A Bolyai-kutatás szakma lett ... Van egyébként valami "varázsfuvolás « a nem euklideszi geometria történetében. Talán épp azért is maradhat örökre ifú, és matematikai meg fizikai tudásunk bővületével ezért késztethet újra meg újra Bolyai János - akár egy odavetett kézírásos mondatával - elődként való felismerésre későbbi nagy eredményekhez és elméletekhez."

\section{Irodalom}

Bedőházi János: A két Bolyai. Marosvásárhely, 1897.

Benkő Samu: Bolyai János vallomásai. Irodalmi Könyvkiadó, Bukarest, 1968 (Negyedik kiadás: Mundus, Budapest, 2002).

Benkő Samu: Apa és fiú (Bolyai tanulmányok). Magvetö Könyvkiadó, Budapest, 1978.

Dávid Lajos: $\quad$ A két Bolyai élete és munkássága. Budapest, 1923 (Második bővített kiadás: Gondolat, Budapest, 1979).

Kiss Elemér: $\quad$ Notes on János Bolyai's Researches in Number Theory. Historia Mathematica, San Diego, 26 (1999), No. 1. 6876. 


\section{EME}

Kiss Elemér: $\quad$ Matematikai kincsek Bolyai János kéziratos hagyatékából. Akadémiai Kiadó, Typotex Kft., Budapest, 1999.

Krizek, M., Luca, F., Somer, L.: 17 Lectures on Fermat Numbers. Springer, 2004.

Stäckel Pál: $\quad$ Bolyai Farkas és Bolyai János geometriai vizsgálatai. III., Budapest, 1914.

Szénássy Barna: Adalékok a két Bolyai felfedezésének történetéhez. Matematikai Lapok, Budapest, 29 (1980), 1-3. 133-140.

Tóth Imre: $\quad$ A nem-euklidészi geometria filozófiai jelentösége. Korunk, 16 (1960), 1. 9-15.

Vekerdi László: A Bolyai-gyüjtemény a Bolyai-kutatásban. = Bolyai-emlékkönyv. Vince Kiadó, Budapest, 2004.

Vekerdi László: Változók és konstansok a Bolyai-kutatásban. = Természet Világa, Bolyai-emlékszám, Budapest, 2003. 136140. 